\title{
Analysis of Bed Occupancy Rate (BOR) in Terms of Internal Factors (Procedures, Doctor, Nurse, Facilities and Infrastructure)
}

\author{
Sandu Siyoto ${ }^{1} \&$ Albert Ronald Tule ${ }^{1}$ \\ ${ }^{1}$ Sekolah Tinggi Ilmu Kesahatan Surya Mitra Husada, Jl. Manila, No. 37, Sumberece, Tosaren, Pesantren, Kediri, \\ East Java 64133, Indonesia \\ Correspondence: Sandu Siyoto, Sekolah Tinggi Ilmu Kesehatan Surya Mitra Husada, Jl. Manila, No. 37, \\ Sumberece, Tosaren, Pesantren, Kediri, East Java 64133, Indonesia. E-mail: dr.sandu.siyoto@gmail.com
}

Received: August 14, 2019 Accepted: November 11, 2019 Online Published: November 13, 2019

doi:10.5539/gjhs.v11n13p77 URL: https://doi.org/10.5539/gjhs.v11n13p77

\begin{abstract}
The purpose of the study was to describe service procedures, doctor services, nurse services, facilities and infrastructure, and Bed Occupancy Rate (BOR) and to determine the effect of service procedures, doctor services, nurse services, facilities and infrastructure on bed occupancy rates (BOR). This research was conducted at Caruban Hospital with a sample of 214 people drawn randomly from 480 populations, data were collected by questionnaire and analyzed by descriptive and ordinal regression. The results of the data analysis show that service presiders, doctor services, nurse services, facilities and infrastructure, and bed occupancy behavior (BOR) are in the "good" category and there is an influence of service procedure, doctor services, nurse services, and facilities and infrastructure on behavior bed occupancy (BOR).
\end{abstract}

Keywords: service procedures, doctor services, nurse services, facilities and infrastructure, bed occupancy rate (BOR)

\section{Introduction}

Measurement of the performance of a hospital can be known through several indicators. Frequently used indicators are: Bed Occupancy Rate (BOR) (Keegan et al., 2010; Harrison et al., 2005), Average Length of Stay (ALOS) (Shi, 1996), Bed Turn Over (BOT) (Goshtasebi et al., 2009), Internal Turn Over (TOI) (Cotino, 2002; Li, 2013), Net Death Rate (NDR) (Aiken, 2000; Aiken et al., 2008), Gross Death Rate (GDR) (Hartz et al, 1989), and the average clinic visit per day (MOH, 2015).

The utilization of hospitalization in the hospital or patient satisfaction can be described by the Hospital BOR data. Bed Occupancy Rate (BOR) is one of the indicators of Hospital performance stating the percentage of bed usage at the one-time unit. This indicator provides an overview of the level of utilization of beds in the hospital. The ideal BOR value is $60-85 \%$. The low BOR indicates that the patient's decision to utilize hospitalization at the Sakiut House is still low. Low BOR data is one of the basic management to make efforts to improve the efficiency of beds at the hospital and at the same time can be used for hospital resource evaluation and planning including Caruban Hospital Madiun (Nwagbara et al., 2016).

Some approaches can be used to determine the factors that influence the BOR number and other indicators such as utility analysis, market analysis (marketing) and system approach analysis. Utility analysis focuses on the BOR approach with the facilities provided or offered by the hospital to patients, market analysis emphasizes the BOR approach with marketing reviews from the consumer's perspective, while the system analysis reviews the BOR through operations that occur in the hospital as a system that includes the stages of input, process, and output. Seeing problems in the hospital either at the section level or as a whole it will be easier and more representative to review the BOR through system analysis (Sulistyono, 2012).

To be able to provide good service a hospital must meet several standard requirements which include input standards, process standards and output standards (Donabedian, 2005). The input factor consists of elements of infrastructure, energy, methods, and budget. To meet the standard process must be considered the processes that occur such as the process of nursing care, service delivery process, time of service, continuity of service. Whereas output standards, for example, are indicators that can be used to measure Hospital performance in this case including Bed Occupancy Rate (BOR). The purpose of this study was to determine the internal factors that affect 
the utilization of inpatient beds (Utility rate) in Caruban Hospital Madiun. There is currently a lack of data surrounding hospitals in the Madiun.

\section{Method}

The design of this study is analytical with the approach Cross-Sectional. A total of 214 samples calculated using Krejcie and Morgan's (1970)'s table from 480 of the population taken by simple Random sampling. The research instrument is questionnaire with consisting of characteristics respondent (age, gender, education, job, length of stay (day)), five variables (Service Procedure, Doctor services, Nurse Services, Facilities and infrastructure), and the measurement of each variable by scales less, enough, and well. Before collecting data, we conducted a pilot project for validity and reliability instrument that results showed all items on four variables are valid and the instrument is reliable since the Crombach alpha coefficient more than 0.7 (Hair et al., 2007). Therefore, the instruments are qualified for collecting data. Moreover, data was analyzed by Ordinal regression since research data on the ordinal scale.

\section{Results}

Institutional ethics approval was gained prior to the progression of the study, and informed consent was sought from those who filled out the questionnaire.

Table 1. Characteristics frequency of respondents

\begin{tabular}{|c|c|c|c|}
\hline Characteristics & Interval & Frequency & Percentage \\
\hline \multirow{5}{*}{ Age } & $<20$ & 24 & 11.21 \\
\hline & $20-35$ & 74 & 34.58 \\
\hline & $36-55$ & 97 & 45.33 \\
\hline & $>55$ & 19 & 8.88 \\
\hline & Total & 214 & 100.00 \\
\hline \multirow{3}{*}{ Gender } & Male & 90 & 42.06 \\
\hline & Female & 124 & 57.94 \\
\hline & Total & 214 & 100.00 \\
\hline \multirow{5}{*}{ Education } & Elementary School & 22 & 10.28 \\
\hline & Junior Secondary School & 30 & 14.02 \\
\hline & Senior Secondary School & 103 & 48.13 \\
\hline & University & 59 & 27.57 \\
\hline & Total & 214 & 100.00 \\
\hline \multirow{5}{*}{ Job } & Not Working & 40 & 18.69 \\
\hline & Entrepreneur & 65 & 30.37 \\
\hline & Private & 52 & 24.30 \\
\hline & Government Employee & 57 & 26.64 \\
\hline & Total & 214 & 100.00 \\
\hline \multirow{4}{*}{ Length of stay (days) } & $3-4$ & 73 & 34.11 \\
\hline & $5-7$ & 84 & 39.25 \\
\hline & $>7$ & 57 & 26.64 \\
\hline & Total & 214 & 100.00 \\
\hline
\end{tabular}

Based on Table 1 presents the characteristics of the respondents involved in the study. The age frequency of most respondents is in the 36-55 year interval (45.33\%) while the smallest is in the $<20$-year interval $(11.21 \%)$. In terms of gender, respondents are dominated by women $(57.94 \%)$ and the rest are Male. From the education side, most respondents were educated at Senior Secondary School (48.13\%) and the lowest was at Elementary School 
(10.28\%). Respondents had the most professions as Entrepreneurs (30.37\%), followed by Government Employees and Private, and Not Working (18.69\%). Length of stay (days) of respondents at the hospital, the highest frequency at $5-7$ days $(39.25 \%)$ and the smallest at $>7$ days $(26.64 \%)$.

Table 2. Variable frequency

\begin{tabular}{llll}
\hline Variables & Scale & Frequency & Percentage \\
\hline \multirow{3}{*}{ Service procedure } & Less & 14 & 6.54 \\
& Enough & 80 & 37.38 \\
& Good & 120 & 56.07 \\
& Total & 214 & 100.00 \\
\hline \multirow{3}{*}{ Doctor services } & Less & 16 & 7.48 \\
& Enough & 91 & 42.52 \\
& Good & 107 & 50.00 \\
Nurse services & Total & 214 & 100.00 \\
\hline & Less & 7 & 3.27 \\
Facilities and Infrastructure & Enough & 54 & 25.23 \\
& Good & 153 & 71.50 \\
& Total & 214 & 100.00 \\
\hline Bed Occupancy Rate (BOR) & Less & 26 & 12.15 \\
& Enough & 91 & 42.52 \\
& Good & 97 & 45.33 \\
& Total & 214 & 100.00 \\
\hline
\end{tabular}

Table 2 provides information that the highest frequency $(71.50 \%)$ chosen by respondents for the good scale is the nurse service variable while the lowest (45.33\%) is in the Facilities and Infrastructure variable. For enough scale, the highest frequency $(42.52 \%)$ chosen by respondents falls on the doctor services variable and Facilities and Infrastructure while the lowest $(25.23 \%)$ falls on the nurse services variable. Furthermore, for the less scale, the highest frequency (7.48\%) chosen by respondents falls on the Doctor Services variable while the lowest (3.27\%) falls on nurse services. Frequency trend data in table 1 can be calculated that more than $87 \%$ of respondents rated more than enough with the highest frequency in the Nurse Services variable $(97.73 \%)$ followed by the Bed Occupancy Rate (BOR) variable $(94.39 \%)$, the Service procedure variable $(93.45 \%)$, Doctor services $(92.52 \%)$, and Facilities and Infrastructure variables $(87.85 \%)$. 
Table 3. Ordinal regression results

\begin{tabular}{lllllll}
\hline \multirow{3}{*}{ Threshold } & {$[$ Less=1] } & Estimates & Std. Error & Wald & df & Sig. \\
& {$[$ Enough=2] } & 7.801 & $2.1,01$ & 10.477 & 1 & 0.001 \\
& {$[$ Well=3] } & 16.050 & 2.027 & 25.456 & 1 & 0.000 \\
Location & Service procedure & 23.990 & 5.788 & 26.445 & 1 & 0.000 \\
& Doctor services & 0.425 & 0.126 & 7.970 & 1 & 0.029 \\
& Nurse services & 0.456 & 0.111 & 6.999 & 1 & 0.018 \\
& Facilities and Infrastructure & 0.327 & 0.201 & 5.798 & 1 & 0.005 \\
& 0.567 & 0.101 & 16.745 & 1 & 0.000 \\
\hline
\end{tabular}

Dependent Variable: Bed Occupancy Rate (BOR).

Ordinal regression is used to examine the effect of each variable of service procedures, doctor services, nurse services, and facilities and infrastructure on the Bed Occupancy Rate (BOR) in Caruban Hospital Madiun with calculations using the SPSS application with the results given in table 3. Based on table 3, it can be said that the service procedure, doctor services, nurse service, and facilities and infrastructure each influence the Bed Occupancy Rate (BOR) in Caruban Hospital Madiun with the Sig value of each variable $<0.05$.

\section{Discussion}

\subsection{Service Procedure}

Modern studies of service in Indonesian hospitals must take into account the recent restructuring of the public healthcare system as a whole. In 19991, the public healthcare sector, along with much of Indonesia's regional governance was decentralized, with more authority given to the respective hospitals of their staff and the level of care they provided to their patients (Maharani et al., 2015).

In the wake of the financial crisis of 1997 to 1998, Indonesian healthcare utilization dropped sharply all across the country, with lowered spending rates and lower healthcare service offerings available to the populace (Waters et al., 2003). In recent years, studies have focused on a wide range of aspects and quality markers of Indonesian hospitals, such as nursing knowledge (Fathoni et al., 2010; Fathoni et al., 2013), the influence of the quality of service on the outcomes of patients (Susanti, 2015), as well as assorted costs such as those of recovery beds (Suwandono et al., 2001) and the overall level of care rendered to children. However, there are limited studies as to the utilization rates of hospitals in Indonesia as a whole as well as the Madiun Regency in particular.

The results of the study showed that the majority of respondents stated that the service procedures at Caruban Madiun Hospital were good. Hospitals as health facilities that provide health services to the community have a very strategic role in accelerating the improvement of public health status. Hospitals are required to provide quality services in accordance with established standards or procedures and can be reached by all levels of society (Duckett, 1983). Standard is the ideal or highest and perfect level of achievement that is used as the minimum acceptance limit (Aditama, 2013).

Hospital service procedures provide services such as administrative services, outpatient services, inpatient services, emergency services, either general patients or insurance patients or BPJS. Patients can often face serious delays in seeking service. Often, patients enter hospitals in the region expecting to be treated immediately and are instead met with mandatory registration requirements which might end in the patient failing to receive a bed altogether. The service procedures of Caruban Hospital are more or less standard for the region. As a result, patients have come to expect this level of service when seeking care.

\subsection{Doctor Services}

The results of the study showed that the majority of respondents stated that the Doctor's Service at Caruban Hospital Madiun was good. Doctors are the most influential element in determining the quality of hospital services for patients. The doctor can be considered the heart of the hospital. Its main function is to provide medical services to patients of the highest quality by using procedures and techniques based on medical science and ethics that are valid and accountable (Aditama, 2013). The doctor's technical skills are in line with the hope of making patients loyal to the hospital so that there is more interest in returning to hospital care. Patients will feel comfortable being served by a doctor who is able to build good interpersonal relationships with patients. Having a sense of comfort will make the patient happy to be handled by the doctor concerned and not reluctant to go back to the same doctor 
for treatment when experiencing health problems (Pohan, 2013). Good doctor services will make patients feel satisfied with health services and think about using health services again when they need them.

Everyone's perception changes depending on what they judge and how they judge. Because perceptions are influenced by several factors, Jacobalis (2010) argues that consumer perceptions of service quality are influenced by several factors including age, gender, occupation, education level, socio-economic, culture, physical environment and personality, and patient experience. Education has an interest in the need to seek health services. Education affects what will be done. This is reflected in the low education knowledge, attitudes, and behaviors associated with the use of low health services. One's education will influence awareness of the importance of health facilities for oneself and the environment so as to encourage the need for health care and the selection of health services (Andreassen, 1997). Doctor services influence decisions in utilizing health services even though most physician services are good, but there are some areas of the results that indicate that respondents who are not satisfied with the doctor's services are doctors who do not know the type of disease and treatment procedures and there are a small number of respondents who state that doctors do not explain which must be done.

The results showed that the doctor's service at Caruban Hospital in Madiun Regency can be proven from the seriousness of the doctor is listening to patient complaints and doctors did not distinguish in providing health services, but there were a small number of respondents who stated that the doctor did not explain the actions taken and did not explain the disease and procedures actions that have been taken. Patient's perceptions and behavior are influenced by educational, occupational, socioeconomic and cultural factors that are inherent in the community in utilizing health services.

\subsection{Nurse Services}

The results of the study showed that most of the respondents stated that Nurse Services at Caruban Hospital Madiun were good. The attitude of nurses in providing services is a variable that has a priority scale to be improved by hospital management. Keep in mind that a hospital is a business unit in the service sector, so service quality will determine the success of its activities. While nurses are components of hospitals that are directly related to patients as consumers (Azwar, 2010). Awareness of medical personnel for efficient service from inpatients will give a good impression to the patient.

The results of the study put forward by Hayati (2010) in his study that if nurses do not care in providing nursing services to patients will have a negative impact on patients so that patients will feel fear, worry, loss of control, and despair. In addition, patients will feel competitive, feel that nothing will help, and the possibility of pain will increase, the patient's healing process will last longer, and interpersonal relationships between nurses and patients are not yet established. According to researchers, the attitude is an important aspect that must be done by nurses in nursing practice. Nursing services based on attitudes shown or carried out effectively can improve health and improve the quality of health services.

From the description above, clearly most respondents stated that the services of nurses at the Caruban Regional Hospital in Madiun District are good, this is indicated by nurses to serve patients kindly and politely in providing therapy and doing services, but not all respondents stated that the service Well, there are a small number of respondents (39.8\%) who say that nursing services are lacking, because in helping meet spiritual needs it is considered by a small number of respondents to be lacking. This can be understood because in providing spiritual needs at the hospital there is a team of its own to meet the spiritual needs of patients.

\subsection{Facilities and Infrastructure}

The results showed that almost half of the respondents stated that the facilities and infrastructure in the Caruban Regional Hospital in Madiun District were good. Health service infrastructure facilities can be defined as a process of cooperation in the efficient use of all health facilities and infrastructure to provide professional services in the field of facilities and infrastructure in the process of health services that are effective and efficient too (Muhammad, 2010). Completeness of good infrastructure is very important in creating customer satisfaction. Hau and Omar (2014) state that service quality is more difficult to evaluate than the quality of goods. With good infrastructure facilities, the utilization of beds will also increase, because patients feel their health will be guaranteed by complete infrastructure facilities (Pribadi, 2017).

From the description above it is clear the facilities and infrastructure in the Hospital are quite good, but there are some that must be improved in accordance with the statements of respondents such as the cleanliness of the bathroom and also health equipment facilities as well as needs to be fixed. Consumers will decide to use or utilize health care advice based on the behavior of the factors that influence it. Hospital hygiene and sanitation programs are very expensive, so often hospital directors/management disagree on the grounds of budget constraints (Borghi 
et al., 2002). Though this antimicrobial resistance control program actually provides many benefits, such as reducing the risk of surgery, chemotherapy, and long-term benefits to prevent the occurrence of total resistance or the return of the medical world to the era before antibiotics (Kollef et al., 1989; Roberts et al., 2009). In addition to key hand hygiene, safety, surface cleanliness over time, easy access, heating, ventilation, and air conditioning, and water systems are used to play an important role in protecting officers and patients (Boyce et al., 2009).

\subsection{Bed Occupancy Rate (BOR)}

The results of the study showed that the majority of respondents stated that the bed occupancy rate (BOR) in Caruban Hospital Madiun was good. To find out the level of benefits, the quality, and efficiency of hospital services require an indicator (Hull, 2018). In addition to the available information, it means that there must be a parameter value that will be used as an appealing value between the fact and the desired standard. The utilization of hospitalization in the hospital or patient satisfaction can be explained by the BOR Hospital data. Bed Occupancy Rate (BOR) is one of the hospital performance indicators that states the percentage of use of beds in one unit of time (Belciug \& Gorunescu, 2015). This indicator provides an overview of the low utilization rates of hospital beds. The ideal BOR value is $60-85 \%$. The low BOR indicates that the patient's decision to utilize hospitalization at the Sakiut House is still low. Low BOR data is one of the basic management to make efforts to improve the efficiency of hospital beds (Jones, 2015) and at the same time can be used for evaluation and planning of hospital resources, including the Caruban Hospital Madiun.

4.6 The Effect of Service Procedures, Doctor Services, Nurse Services, and Facilities and Infrastructure to Bed Occupancy Rate (BOR).

The ordinal regression results show that service procedures, doctor services, nurse services, and facilities and infrastructure affect to bed occupancy rate (BOR). This shows that all four factors must be considered in managing a hospital where patients can determine their choice to be treated. This is understandable because of the limited knowledge of patients regarding nursing services and doctors who may not be well understood. However, facilities and infrastructure are things that can be directly felt and seen by patients (Astley et al., 2016).

Hospitalization by Crosby in Nasution (2015) is an ongoing patient activity to the hospital to get health services that last more than 24 hours. In particular, inpatient services are intended for patients or patients who need continuous care until healing occurs. Hospital service procedures are very important to clarify the services available at the hospital, but this service procedure is poorly understood by the community, and this service procedure is more likely for hospital employees to perform health services in accordance with the procedures applied by the Hospital. Therefore, from the results of the study, many respondents stated that the hospital service procedure was good but did not affect the utilization of the inpatient bed (utility rate). This study is limited in that its sample size is relatively small, and therefore cannot be accurately generalized to the rest of Indonesia as a whole.

\section{Conclusion and Recommendations}

Overall, service procedures, doctor services, nurse Services facilities and infrastructure and bed occupancy rate (BOR) are in a good category. All Factors service procedures, doctor services, nurse Services facilities and infrastructure that have an influence on the bed occupancy rate (BOR) in Caruban Hospital Madiun.

It is recommended that hospitals pay attention to aspects that can improve work effectiveness whether it is doctors, nurses, pharmacists or other medical support staff and make improvements to these aspects so that the achievement of hospital goals can indeed be measured by the effectiveness of their employees. In order to support efforts to improve the quality of services, things that are still lacking the need to be immediately corrected, hoped that further research will use larger samples, involving more hospitals, as well as wider locations, so that conclusions better describe the state of the study sample, and minimize bias in research.

\section{Competing Interests Statement}

The authors declare that there are no competing or potential conflicts of interest.

\section{References}

Aditama. (2013). Three aspects of service quality assessment. Retrieved 11 November, 2017, from http://closehealthservices.net/index.php/component/content/article/19-headline/1194-tiga-aspek-peningkatmutu-pelayanan

Aiken, L. H., Clarke, S. P., \& Sloane, D. M. (2000). Hospital restructuring: does it adversely affect care and outcomes? Journal of Nursing Administration, 30(10), 457-465. https://doi.org/10.1097/00005110-200010000-00003 
Aiken, L. H., Clarke, S. P., Sloane, D. M., Lake, E. T., \& Cheney, T. (2008). Effects of hospital care environment on patient mortality and nurse outcomes. The Journal of nursing administration, 38(5), 223. https://doi.org/10.1097/01.NNA.0000312773.42352.d7

Andreassen, T. W., \& Lindestad, B. (1997). Customer loyalty and complex services: the impact of corporate image on quality, customer satisfaction and loyalty for customers with varying degrees of service expertise. $\begin{array}{lllll}\text { International Journal of Service Industry Management, } & 9(1), & \text { 7-23. }\end{array}$ https://doi.org/10.1108/09564239810199923

Astley, C., Ranasinghe, I., Brieger, D., Ellis, C., Redfern, J., Briffa, T., ... \& Driscoll, A. (2016). Expertise and infrastructure capacity impacts acute coronary syndrome outcomes. Heart, Lung and Circulation, 25, S271. https://doi.org/10.1016/j.hlc.2016.06.632

Azwar. S. (2010). Penyusunan skala psikologi [Preparation of the Psychology Scale]. Jakarta: Student Library.

Belciug, S., \& Gorunescu, F. (2015). Improving hospital bed occupancy and resource utilization through queuing modeling and evolutionary computation. Journal of biomedical informatics, 53, 261-269. https://doi.org/10.1016/j.jbi.2014.11.010

Borghi, J., Guinness, L., Ouedraogo, J., \& Curtis, V. (2002). Is hygiene promotion cost-effective? A case study in Burkina Faso. Tropical Medicine \& International Health, 7(11), 960-969. https://doi.org/10.1046/j.1365-3156.2002.00954.x

Boyce, J., Chartier, Y., Chraiti, M., Cookson, B., Damani, N., \& Dharan, S. (2009). WHO guidelines on hand hygiene in health care. Geneva: World Health Organization.

Donabedian, A. (2005). Evaluating the quality of medical care. Milbank Quarterly, 83(4), 691-729. https://doi.org/10.1111/j.1468-0009.2005.00397.x

Duckett, S. J. (1983). Assuring hospital standards: the introduction of hospital accreditation in Australia. $\begin{array}{llll}\text { Australian Journal of Public } & \text { Administration, }\end{array}$ https://doi.org/10.1111/j.1467-8500.1983.tb00976.x

Fathoni, M., Sangchan, H., \& Songwathana, P. (2010). Triage knowledge and skills among emergency nurses in East Java Province, Indonesia. Australasian Emergency Nursing Journal, 13(4), 153. https://doi.org/10.1016/j.aenj.2010.08.304

Fathoni, M., Sangchan, H., \& Songwathana, P. (2013). Relationships between triage knowledge, training, working experiences and triage skills among emergency nurses in East Java, Indonesia. Nurse Media Journal of Nursing, 3(1), 511-525. https://doi.org/10.14710/nmjn.v3i1.4466

Goshtasebi, A., Vahdaninia, M., Gorgipour, R., Samanpour, A., Maftoon, F., Farzadi, F., \& Ahmadi, F. (2009). Assessing hospital performance by the Pabon Lasso Model. Iranian Journal of Public Health, 38(2), 119-124.

Harrison, G. W., Shafer, A., \& Mackay, M. (2005). Modeling variability in hospital bed occupancy. Health Care Management Science, 8(4), 325-334. https://doi.org/10.1007/s10729-005-4142-8

Hartz, A. J., Krakauer, H., Kuhn, E. M., Young, M., Jacobsen, S. J., Gay, G., ... \& Rimm, A. A. (1989). Hospital characteristics and mortality rates. New England journal of medicine, 321(25), 1720-1725. https://doi.org/10.1056/NEJM198912213212506

Hau, T. C., \& Omar, K. (2014). The Impact of Service Quality on Tourist Satisfaction: The Case Study of Rantau Abang Beach as a Turtle Sanctuary Destination. Mediterranean Journal of Social Sciences, 5(23), 1827-1833. https://doi.org/10.5901/mjss.2014.v5n23p1827

Hull, P. (2018). Estimating Hospital Quality with Quasi-Experimental Data. https://doi.org/10.2139/ssrn.3118358

Jones, R. (2015). Links between bed occupancy, deaths and costs. British Journal of Healthcare Management, 21(11), 544-545. https://doi.org/10.12968/bjhc.2015.21.11.544

Keegan, A. D. (2010). Hospital bed occupancy: more than queuing for a bed. Medical Journal of Australia, 193(5), 291-293. https://doi.org/10.5694/j.1326-5377.2010.tb03910.x

Kollef, M. H., Sherman, G., Ward, S., \& Fraser, V. J. (1999). Inadequate antimicrobial treatment of infections: a risk factor for hospital mortality among critically ill patients. Chest, 115(2), 462-474. https://doi.org/10.1378/chest.115.2.462

Krejcie, R. V., \& Morgan, D. W. (1970). Determining sample size for research activities. Educational and 
Psychological Measurement, 30, 607-610. https://doi.org/10.1177/001316447003000308

Maharani, A., Femina, D., \& Tampubolon, G. (2015). Decentralization in Indonesia: lessons from cost recovery rate of district hospitals. Health Policy and Planning, 30(6), 718-727. https://doi.org/10.1093/heapol/czu049

Muhammad. (2010). The Technical Guidelines for Hospital Infrastructure of class c. Bandung: Afabeta.

Nasution, M. N. (2015). Manajemen Jasa Terpadu: Total Service Management [Integrated Quality Management: Total Service Management]. Bogor. Ghalia Indonesia.

Nwagbara, V. C., Rasiah, R., \& Aslam, M. M. (2016). An approach toward public hospital performance assessment. Medicine, 95(36), e4688. https://doi.org/10.1097/MD.0000000000004688

Pribadi, K. T. (2017). The health care system in Indonesia. In Health Care Systems in Developing Countries in Asia (pp. 131-148). Routledge. https://doi.org/10.4324/9781315586403-6

Roberts, R. R., Hota, B., Ahmad, I., Scott, R. D., Foster, S. D., Abbasi, F., ... \& Naples, J. (2009). Hospital and societal costs of antimicrobial-resistant infections in a Chicago teaching hospital: implications for antibiotic stewardship. Clinical infectious diseases, 49(8), 1175-1184. https://doi.org/10.1086/605630

Shi, L. (1996). Patient and hospital characteristics associated with average length of stay. Health care management review, 21(2), 46-61. https://doi.org/10.1097/00004010-199605000-00007

Sulistyono. (2012). Konstruksi Alat Ukur Psikologi [Construction of Psychology Measurement Tools. Teaching Materials Development Center]. Bandung: Mercu Buana.

Susanti, C.E. (2015). The Influence of Internal Service Quality toward Patient's Behavioral Intention in Inpatient Unit at the Type C General Hospitals in East Java, Indonesia. GSTF Journal of Nursing and Health Care (JNHC), 3(1), 78-88. https://doi.org/10.5176/2345-718X_3.1.106

Suwandono, A., Gani, A., Purwani, S., Blas, E., \& Brugha, R. (2001). Cost recovery beds in public hospitals in Indonesia. Health Policy and Planning, 16(2), 10-18. https://doi.org/10.1093/heapol/16.suppl_2.10

\section{Copyrights}

Copyright for this article is retained by the author(s), with first publication rights granted to the journal.

This is an open-access article distributed under the terms and conditions of the Creative Commons Attribution license (http://creativecommons.org/licenses/by/4.0/). 